\title{
Synthesis and Characterization of Zeolite NaP Using Kaolin Waste as a Source of Silicon and Aluminum
}

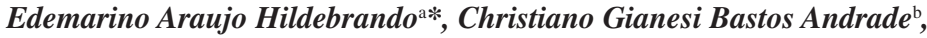 \\ Carlos Augusto Ferreira da Rocha Junior', Rômulo Simões Angélicad, \\ Francisco Rolando Valenzuela-Diaz ${ }^{\mathrm{b}}$, Roberto de Freitas Neves ${ }^{\mathrm{c}}$ \\ ${ }^{a}$ Ceramic Materials Laboratory, Faculty of Materials Engineering, Federal University of Pará - UFPA, \\ CEP 68505-080, Marabá, PA, Brazil \\ ${ }^{\mathrm{b}}$ Particulate Raw Materials and Non-Metallic Solids Laboratory, Department of Metallurgical and \\ Materials Engineering, University of São Paulo - USP, São Paulo, SP, Brazil \\ ${ }^{\mathrm{C}}$ Faculty of Chemical Engineering, Institute of Technology, Federal University of Pará - UFPA, \\ Marabá, PA, Brazil \\ ${ }^{\mathrm{d}}$ Faculty of Geology, Institute of Geosciences, Federal University of Pará - UFPA, Marabá, PA, Brazil
}

Received: June 20, 2013; Revised: January 15, 2014

\begin{abstract}
The synthesis of zeolite $\mathrm{NaP}$ using kaolin waste, from the Amazon region, as a predominant source of silicon and aluminum has been studied. The zeolitisation process occurred in hydrothermal conditions using static autoclaving and the effects of time, temperature, and the $\mathrm{Si} / \mathrm{Al}$ ratio were investigated. The starting material and the phases formed as reaction products were characterized by XRD, SEM and FTIR. The results showed that pure zeolite $\mathrm{NaP}$ is hydrothermally synthesized, at $100{ }^{\circ} \mathrm{C}$ for 20 hours, using metakaolin waste material in alkaline medium in presence of additional silica. The XRD and SEM analyses indicate that the synthesized zeolite presents good crystallinity.
\end{abstract}

Keywords: zeolite P, hydrothermal synthesis, kaolin industrial waste, Amazon region

\section{Introduction}

Zeolites are porous aluminosilicates with a crystalline structure formed by the combination of silica tetrahedra $\left[\mathrm{SiO}_{4}\right]^{4-}$ and alumina $\left[\mathrm{AlO}_{4}\right]^{5-}$, joined by oxygen atoms ${ }^{1}$. Traditionally, these microporous materials are commonly produced from hydrogels aluminates and sodium silicates; however, the production of zeolites from alternative sources of silica and alumina such as ash ${ }^{2}$, volcanic glasses ${ }^{3}$, diatomites ${ }^{4}$ and clays ${ }^{5}$, continue to be investigated. Among the clays, several investigators have studied the preparation of zeolite from kaolin and have been successful in the synthesis of zeolites, mainly $\mathrm{NaA}^{[6]}$, mordenite ${ }^{7}$, faujasites ${ }^{8}$, and zeolite $\mathrm{NaP}^{9,10}$.

According to the International Zeolite Association $(\mathrm{IZA})^{11}$ zeolite NaP has a GIS (gismondine) structure type showing small pores. Such structure results interesting because of its applications both in industry and in environmental protection ${ }^{3,12}$. Usually, this type of zeolite synthesis occurs at temperatures ranging from $70{ }^{\circ} \mathrm{C}$ to $250{ }^{\circ} \mathrm{C}$ during long crystallization times ${ }^{13}$. The standard procedure established by IZA for obtaining zeolite $\mathrm{NaP}$ is based on the works by Rees and Chandreskar ${ }^{9}$ that synthesized this zeolitic phase in hydrothermal conditions at $85^{\circ} \mathrm{C}$ during 60 days, using Indian kaolin as the source of silicon and aluminum. Recently, Acorsi et al. ${ }^{10}$ using Brazilian kaolin from various sources obtained zeolite $\mathrm{NaP}$

*e-mail: edemarino@ufpa.br at $100{ }^{\circ} \mathrm{C}$ in 4 days, using the alkaline fusion procedure. In this context, the efficiency in the synthesis process of this type zeolite requires the appropriate raw materials, time, and crystallization temperature.

Brazil and the U.S. have some of the largest reserves of kaolin in the planet. In Brazil, the state of Pará (Amazon region) stands out for having one of the most important international kaolin deposits for the paper industry ${ }^{14}$. During the processing steps for purifying raw kaolin, waste is produced and stored in settling ponds which occupy large area. This situation presents a problem due to the impact on the environment ${ }^{15}$.

Kaolin waste is unsuitable for use in paper-making industries; however, this material has the potential of being used in other applications, such as: alumina production ${ }^{15}$, refractories ${ }^{16}$, pozzolans ${ }^{17}$ and synthesis of zeolitic materials $^{18-20}$.

The utilization of kaolin waste for the production of $\mathrm{NaP}$ zeolite may be a good alternative to re-use this material. Thus, economic advantages would be obtained over chemical reagents used in processes to obtain zeolites that are relatively expensive.

Therefore, the main purpose of this study was to synthesize zeolite $\mathrm{NaP}$ using kaolin waste from the Amazon region as the main source of silicon and aluminum, improving crystallization time for lower values. 


\section{Material and Methods}

\subsection{Materials}

Kaolin wastes (KW) and metakaolin waste material (CKW), obtained from calcined kaolin waste at $700{ }^{\circ} \mathrm{C}$ for 2 hours were used in the zeolitization process. These materials were obtained from a paper-coating factory located in Pará. Sodium metasilicate pentahydrate $\left(\mathrm{Na}_{2} \mathrm{O}\right.$. $\mathrm{SiO}_{2} \cdot 5 \mathrm{H}_{2} \mathrm{O}$ ) and commercial $\mathrm{NaOH}$ were used as a secondary source of silicon and as a mineralizing agent, respectively.

\subsection{Synthesis}

The zeolitic material was obtained by hydrothermal synthesis in a stainless steel autoclave ( $47.4 \mathrm{~mL}$ capacity) internally coated with Teflon. In the initial series of experiments, the hydrothermal reaction was performed at $115{ }^{\circ} \mathrm{C}$ for 20 hours, the synthesis gel was prepared, by mixing $2.53 \mathrm{~g}$ of kaolin waste, $\mathrm{NaOH}$ and sodium metasilicate (Table 1). The batches' composition was calculated stoichiometricaly with a reaction mixture of $3 \mathrm{Na}_{2} \mathrm{O}-\mathrm{Al}_{2} \mathrm{O}_{3}-\mathrm{xSiO}_{2}-\mathrm{H}_{2} \mathrm{O}$, with values of $\mathrm{x}$ in the range of 3.5 to $5.0 \mathrm{~mol}$. In the second series of experiments, the following conditions of synthesis were evaluated: temperature $\left(90,95,100\right.$ and $115^{\circ} \mathrm{C}$ at 20-hour) and time $(6,20,24$ and 48 hours at a $90{ }^{\circ} \mathrm{C}$ ). The samples were based on molar composition $4 \mathrm{Na}_{2} \mathrm{O}-\mathrm{Al}_{2} \mathrm{O}_{3}-4 \mathrm{SiO}_{2}-\mathrm{H}_{2} \mathrm{O}$ using $2.18 \mathrm{~g}$ of metakaolin waste material, $1.569 \mathrm{~g} \mathrm{NaOH}$ and $4.157 \mathrm{~g}$ of $\mathrm{Na}_{2} \mathrm{O}$. $\mathrm{SiO}_{2} .5 \mathrm{H}_{2} \mathrm{O}$. In none of the experiments was the aging step applied to the gel. The water volume added in the autoclave was $40 \mathrm{~mL}$, and the reactions of zeolitization occurred without agitation. Subsequently, the products of the synthesis formed were washed by filtration, with distilled water up to $\mathrm{pH}$ 7-8, and then subjected to drying at $100{ }^{\circ} \mathrm{C}$ for 24 hours. The synthesis conditions are summarized in Table 1.

\subsection{Materials characterization}

The starting material and the synthesized products were analyzed using X-ray diffraction (XRD), scanning electronic microscopy (SEM) and diffuse reflectance spectroscopy in the infrared Fourier transform (DRIFTS). The XRDs were performed on a diffractometer model X'Pert Pro MPD (Panalytical) using $\mathrm{Cu}-\mathrm{K} \alpha$ radiation $(\lambda=1.5406 \AA$ ) with $\mathrm{Ni} \mathrm{K} \beta$ filter. The scan range was $5^{\circ}$ to $90^{\circ} 2 \theta ; 40 \mathrm{kV}$ and 35 $\mathrm{mA}$. To observe the morphology and the size of the crystals, a Philips SEM brand, model XL30, was used and the samples were previously metalized with a thin gold film in "sputter coater" brand BALZERS equipment. The infrared spectroscopy (FTIR) was performed in a Thermo-Nicolet Magna equipment 560 with 400 to $4000 \mathrm{~cm}^{-1}$ (mid-infrared) scan and $4 \mathrm{~cm}^{-1}$ resolution, using a diffuse reflectance cell.

\section{Results and Discussion}

\subsection{X-ray diffraction $(X R D)$}

Figure 1 shows the XRD patterns of kaolin waste $(\mathrm{KW})$ and synthesized products. This revealed that the kaolin waste was mainly composed of kaolinite. A small amount of quartz was observed by a peak of low intensity at $2 \theta=26.7^{\circ}$. The $\mathrm{SiO}_{2} / \mathrm{Al}_{2} \mathrm{O}_{3}$ ratio is one of the major parameters that guide the formation of the crystalline structure of a zeolite ${ }^{1}$. In XRD patterns of the synthesized products obtained after the zeolitisation process using kaolin waste, the formation of zeolite $\mathrm{NaP}$ was observed through reflections on $2 \theta=12.4^{\circ}$, $17.7^{\circ}, 21.8^{\circ}, 28.2^{\circ}$ and $33.5^{\circ}$, according with data from other studies $^{3,12}$. For the $\mathrm{SiO}_{2} / \mathrm{Al}_{2} \mathrm{O}_{3}$ ratio equal to $3.5 \mathrm{~mol}$, the $\mathrm{X}$-ray diffraction analysis shows the presence of faujasite zeolite in the synthesized sample as evidenced from reflections of low intensity near $2 \theta=6.2^{\circ}, 15.6^{\circ}$ and $30.9^{\circ}$.

Analyzing the change of some peaks observed by XRD patterns of the synthesized products, it is interesting to note that the zeolite $\mathrm{NaP}$ formed is of the cubic and tetragonal

Table 1. Synthesis conditions of samples.

\begin{tabular}{|c|c|c|c|c|c|}
\hline Assay & $\mathrm{SiO}_{2} / \mathrm{Al}_{2} \mathrm{O}_{3}$ & $\mathrm{Na}_{2} \mathrm{O} . \mathrm{SiO}_{2} .5 \mathrm{H}_{2} \mathrm{O}, \mathrm{g}$ & $\mathrm{NaOH}, \mathrm{g}$ & Temperature, ${ }^{\circ} \mathrm{C}$ & Time, h \\
\hline \multicolumn{6}{|c|}{ First series } \\
\hline \multicolumn{6}{|c|}{ Effect of initial $\mathrm{SiO}_{2} / \mathrm{Al}_{2} \mathrm{O}_{3}$} \\
\hline 01 & 3.5 & 3.117 & 1.411 & 115 & 20 \\
\hline 02 & 4.0 & 4.157 & 0.941 & 115 & 20 \\
\hline 03 & 4.5 & 5.196 & 0.471 & 115 & 20 \\
\hline 04 & 4.8 & 5.819 & 0.187 & 115 & 20 \\
\hline 05 & 5.0 & 6.235 & $-\cdots$ & 115 & 20 \\
\hline \multicolumn{6}{|c|}{ Second series } \\
\hline \multicolumn{6}{|c|}{ Effect of crystallization temperature } \\
\hline 01 & 4.0 & 4.157 & 1.569 & 90 & 20 \\
\hline 02 & 4.0 & 4.157 & 1.569 & 95 & 20 \\
\hline 03 & 4.0 & 4.157 & 1.569 & 100 & 20 \\
\hline 04 & 4.0 & 4.157 & 1.569 & 115 & 20 \\
\hline \multicolumn{6}{|c|}{ Effect of crystallization time } \\
\hline 01 & 4.0 & 4.157 & 1.569 & 90 & 6 \\
\hline 02 & 4.0 & 4.157 & 1.569 & 90 & 20 \\
\hline 03 & 4.0 & 4.157 & 1.569 & 90 & 24 \\
\hline 04 & 4.0 & 4.157 & 1.569 & 90 & 48 \\
\hline
\end{tabular}




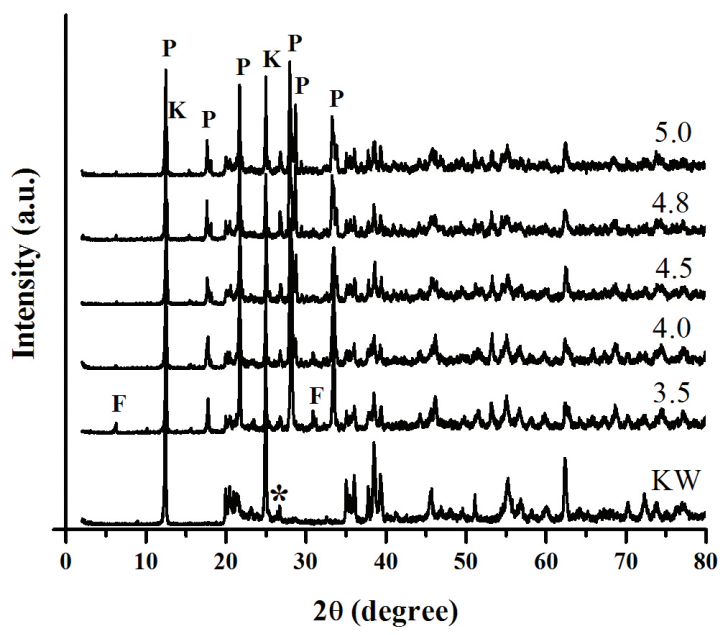

Figure 1. XRD patterns of synthesized products using kaolin waste $(\mathrm{KW})$ to $\mathrm{SiO}_{2} / \mathrm{Al}_{2} \mathrm{O}_{3}$ ratio from 3.5 to $5.0 \mathrm{~mol}$. $\mathrm{P}=$ zeolite $\mathrm{NaP}$, $\mathrm{F}=$ faujasite, $\mathrm{K}=$ kaolinite, ${ }^{*}=$ quartz.

type. The former, predominating in samples with lower $\mathrm{SiO}_{2} /$ $\mathrm{Al}_{2} \mathrm{O}_{3}(3.5$ and $4.0 \mathrm{~mol}$ ), and the latter in the highest ratios. This is justified, for example, by the observation that some simple peaks were divided into twin peaks such as peak (200) at $2 \theta=17.7^{\circ}$ which dismembers to (200) and (002). According to Breck ${ }^{1}$, this phenomena is usually observed when a higher symmetry array turns into a lower symmetry array; in this case, cubic zeolite $\mathrm{NaP}$ to tetragonal zeolite $\mathrm{NaP}$. A similar behavior was observed in Huo et al. ${ }^{21}$ in which successive samples of zeolite NaP were synthesized with two different morphologies. XRD results (Figure 1) indicated that in the synthesized products were found as impurities, quartz and kaolinite, originated from the kaolin waste samples. This fact can be verified by the presence of these mineral phases in the XRD patterns.

Figure 2 shows the results of synthesis reactions using metakaolin waste material. At this stage, the crystallization time and temperature were studied. First, a loss of KW crystallinity is observed from the XRD pattern of CKW, indicating effective metakaolinization at $700{ }^{\circ} \mathrm{C}$ for 2 hours. Metakaolinite is much more reactive and thus a very suitable source for zeolite synthesis ${ }^{22}$. Figure 2 a shows that the formation of zeolite $\mathrm{NaP}$ is induced at $95{ }^{\circ} \mathrm{C}$ and $20 \mathrm{~h}$. At $100{ }^{\circ} \mathrm{C}$ and $20 \mathrm{~h}, \mathrm{NaP}$ appears as a single-phase of high crystallinity according to the strong signals in the XRD pattern. Below and above this temperature range, the competitive phases appear as faujasite and chabazite. Literature reports ${ }^{1,8}$, show that these two types of zeolites can be formed from the same compositional pattern $\left(\mathrm{Na}_{2} \mathrm{O}-\mathrm{Al}_{2} \mathrm{O}_{3}-\mathrm{SiO}_{2}-\mathrm{H}_{2} \mathrm{O}\right)$, thus competing with zeolite $\mathrm{NaP}$.

Figure $2 \mathrm{~b}$ shows that at $90{ }^{\circ} \mathrm{C}$ for a 6-hour reaction time, no zeolitic phase is formed. Only the existence of amorphous material was observed, as well as the presence of a characteristic peak of quartz, which is a constituent of the starting material and, therefore, not a synthesis product. However, by increasing reaction time (up to 20 hours), characteristic reflections of zeolite $\mathrm{NaP}$ are observed.

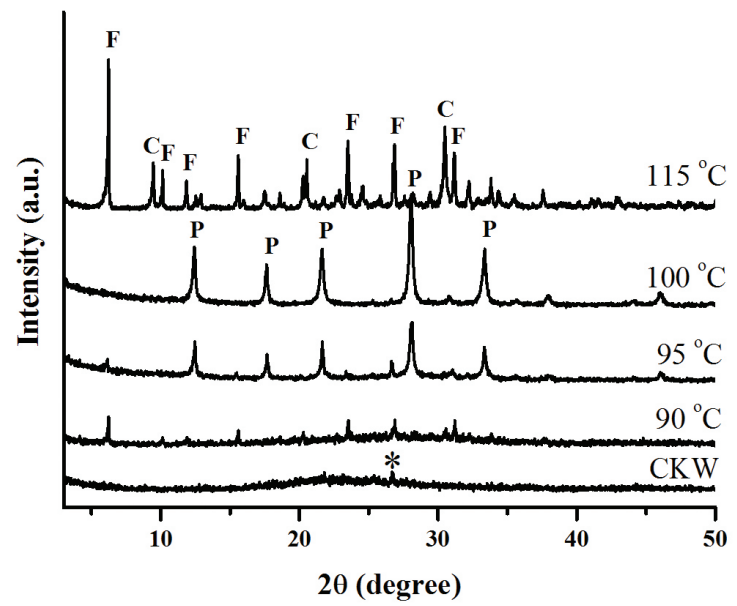

(a)

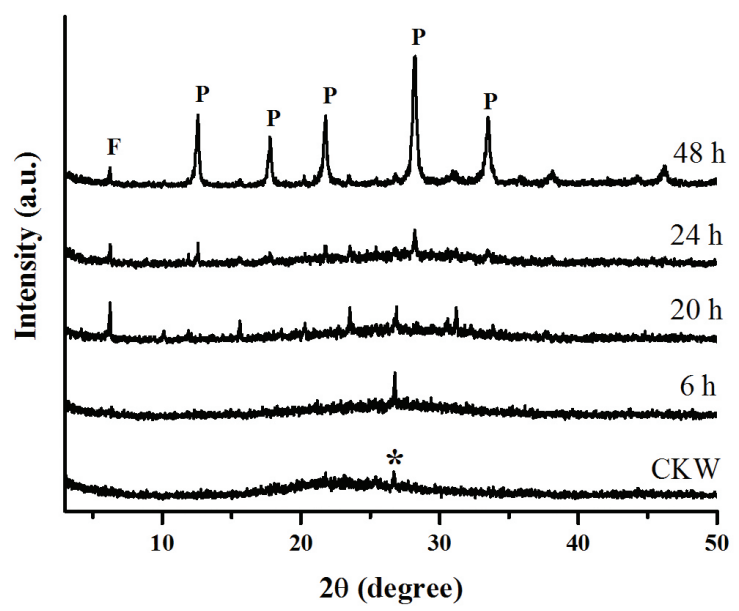

(b)

Figure 2. XRD patterns of synthesized products using metakaolin waste material $(\mathrm{CKW})$ at different (a) temperatures for 20 hours; and different (b) times of crystallization at $90{ }^{\circ} \mathrm{C}$. $\mathrm{P}=$ zeolite $\mathrm{NaP}$, $\mathrm{F}=$ faujasite, $\mathrm{C}=$ chabazite, ${ }^{*}=$ quartz.

Competing with it, faujasite-type zeolite, a predominance of zeolite $\mathrm{NaP}$ occurs after a 48-hour reaction time.

\subsection{Scanning electron microscope (SEM)}

The progress of zeolitization reactions can be observed through changes in the morphology of the starting material and synthesis products. The SEM images of Figure 3 allow verifying that the kaolin waste (Figure 3a) consists predominantly of agglomerated particles with stacking booklet type and pseudo-hexagonal crystals characteristic of kaolinite. In the metakaolin waste material, Figure $3 b$, the stacking is modified but the form is maintained ${ }^{18}$. The morphology of the synthesized samples can be observed in the micrographs of Figures $3 \mathrm{c}$ and d they are similar to those presented by Zubowa et al. ${ }^{13}$, in which zeolite $\mathrm{NaP}$ is identified by pseudo-spherical forms constituted by small plates, which form polycrystals with an average size of approximately 7.0-9.0 $\mu \mathrm{m}$. Similar results were also reported 


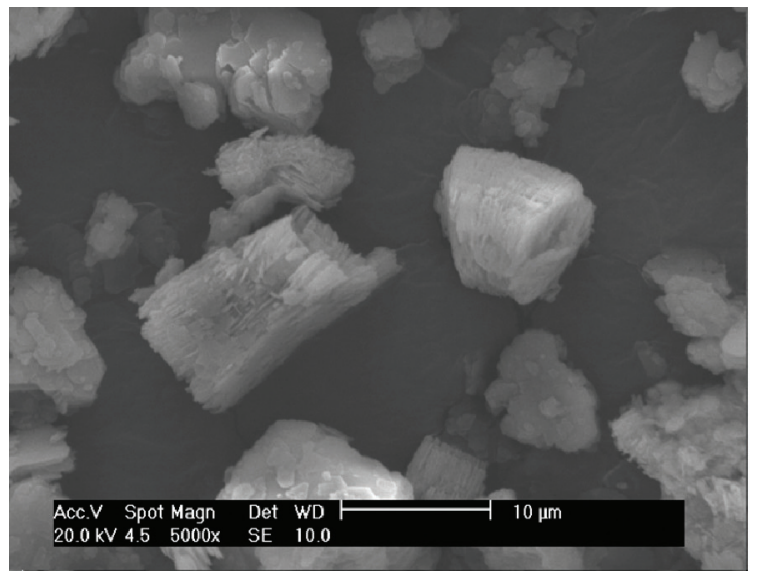

(a)

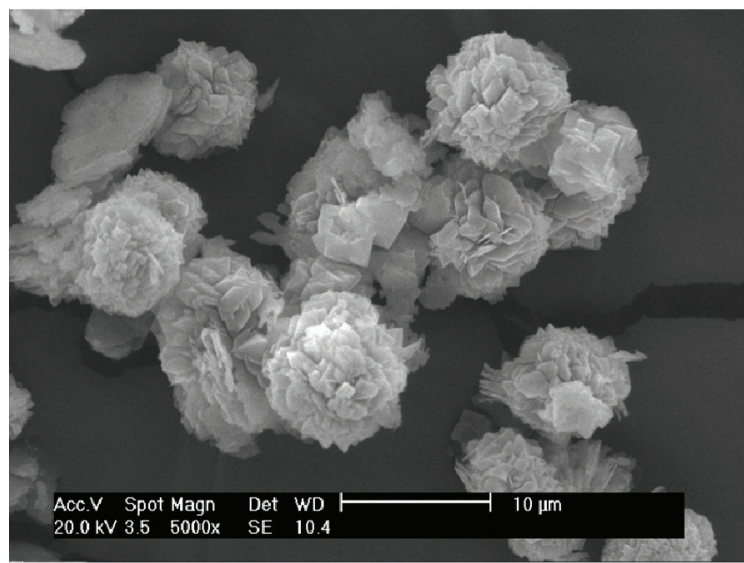

(c)

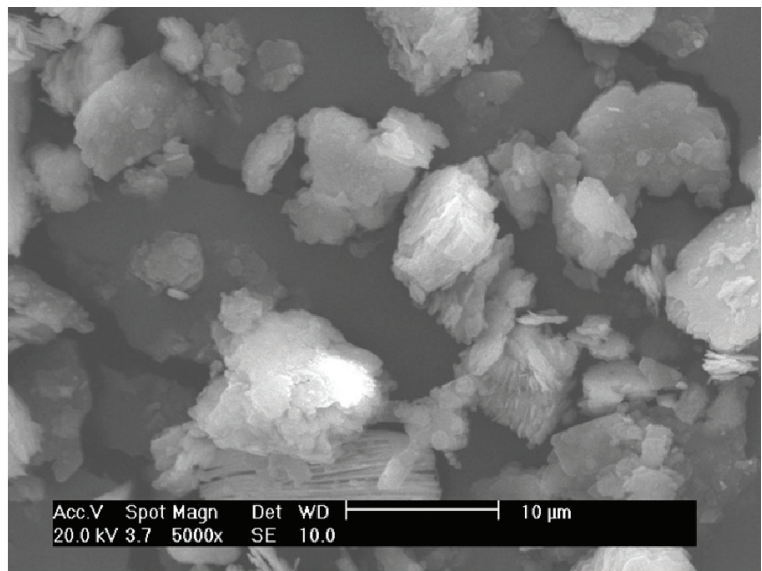

(b)

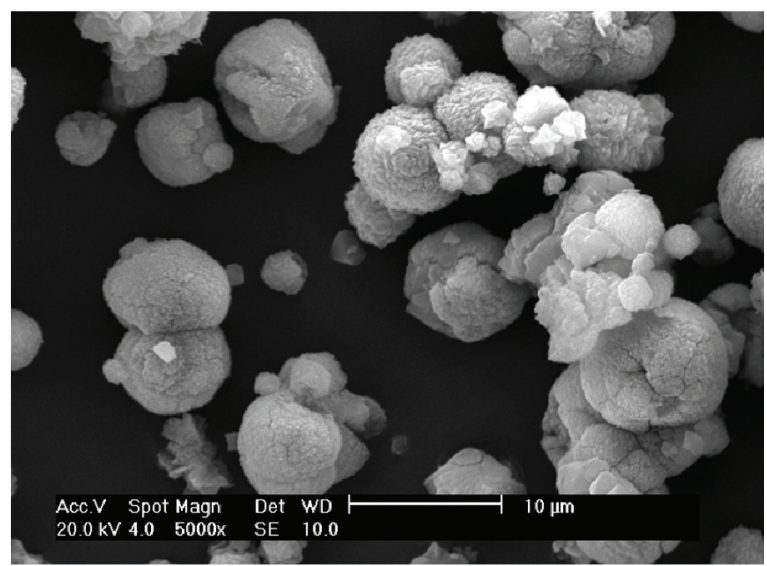

(d)

Figure 3. SEM images: (a) kaolin waste, (b) metakaolin waste material; (c) synthesized sample at $115^{\circ} \mathrm{C} / 20$ hours using kaolin waste; (d) synthesized sample at $100{ }^{\circ} \mathrm{C} / 20$ hours from metakaolin waste material.

by Rees and Chandrasekhar ${ }^{9}$ who obtained zeolite $\mathrm{NaP}$ with spherulitic habit, and $10.0 \mathrm{~mm}$ in diameter synthesized from Indian kaolinite. Figure $3 \mathrm{c}$ also illustrates the coexistence of a certain amount of unreacted kaolinite during the process, which relates with the results from XRD in Figure 1. The better definition in crystal morphology observed in Figure 3d, in relation to those shown in Figure 3c, can be attributed to the increase in the crystallization of the zeolite $\mathrm{NaP}$ in the conditions studied.

\subsection{IR-spectroscopy (FTIR)}

The vibrational spectra of Figure 4 show the changes that occur from the starting material to the synthesis products. In the KW sample (spectrum a in Figure 4), there are stretch bands of $\mathrm{OH}$ group at 3697, 3653 and $3621 \mathrm{~cm}^{-1}$, characteristic of kaolinite. Their absence in the CKW sample (spectrum b in Figure 4) demonstrates the conversion of kaolin into metakaolin ${ }^{23}$.

For the synthesized products (spectra c and d in Figure 4), the bands with a maximum at 3420 and $1646 \mathrm{~cm}^{-1}$ are peculiar of vibrations of functional groups of $\mathrm{OH}$ type and are ascribed to water with zeolitic nature. Similar behavior was found by

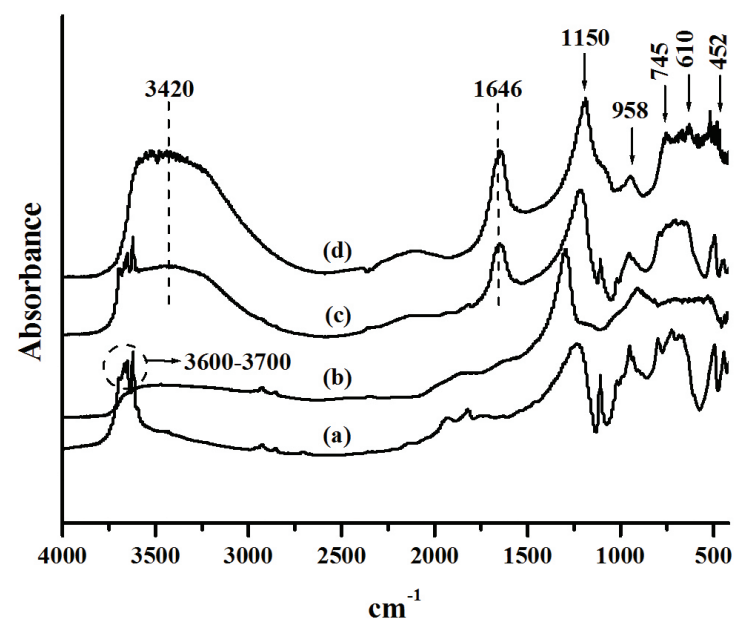

Figure 4. FTIR spectra of the samples (a) kaolin waste; (b) metakaolin waste material; (c) synthesized sample at $115{ }^{\circ} \mathrm{C} / 20$ hours from kaolin waste; (d) synthesized sample at $100{ }^{\circ} \mathrm{C} / 20$ hours from metakaolin waste material. 
Albert et al. ${ }^{24}$ while obtaining highly crystalline zeolite NaP. According to Huo et al. ${ }^{21}$, frequencies near $1000 \mathrm{~cm}^{-1}$ are ascribed to asymmetric stretching of bonds $\mathrm{Si}-\mathrm{O}$ or Al-O. Vibrations at $435 \mathrm{~cm}^{-1}$ are related to the deformation mode of the same bonds. The peaks near 680 and $745 \mathrm{~cm}^{-1}$ are assigned to symmetric T-O-T vibrations ( $\mathrm{T}=\mathrm{Si}, \mathrm{Al})$ of zeolite $\mathrm{Na} P$ framework structure. The peak at $610 \mathrm{~cm}^{-1}$ indicates the double ring vibration which constitutes the structure of the zeolitic phase ${ }^{25}$.

\section{Conclusions}

Kaolin waste from the Amazon region is a promising source of silicon and aluminum for the synthesis

\section{References}

1. Breck DW. Zeolitic Molecular Sieves. New York: Wiley; 1974.

2. Rocha CAF Jr, Santos SCA, Souza CAG, Angélica RS and Neves RF. Síntese de zeólitas a partir de cinza volante de caldeiras: caracterização física, química e mineralógica. Cerâmica. 2012; 58(345):43-52. http://dx.doi.org/10.1590/ S0366-69132012000100008

3. Faghihian H and Kamali M. Synthesis of Na-P zeolite from perlite and study of its ability to remove cyanide from liquid wastes. International Journal of Environment and Pollution. 2003; 19(6):557-566.

4. Sanhueza V, Kelm U, Cid R and López-Escobar L. Synthesis of ZSM-5 from diatomite: a case of zeolite synthesis from a natural material. Journal of Chemical Technology and Biotechnology. 2004; 79:686-690. http://dx.doi.org/10.1002/ jctb. 1022

5. Mezni M, Hamzaoui A, Hamdi N and Srasra E. Synthesis of zeolites from the low-grade Tunisian natural illite by two different methods. Applied Clay Science. 2011; (52):209-218. http://dx.doi.org/10.1016/j.clay.2011.02.017

6. Loiola AR, Andrade JCRA, Sasaki JM and Silva LRD. Structural analysis of zeolite NaA synthesized by a cost-effective hydrothermal method using kaolin and its use as water softener. Journal of Colloid and Interface Science. 2012; 367:34-39. http://dx.doi.org/10.1016/j.jcis.2010.11.026

7. Mignoni ML, Petkowicz DI, Machado NRCF and Pergher SBC. Synthesis of mordenite using kaolin as $\mathrm{Si}$ and $\mathrm{Al}$ source. Applied Clay Science. 2008; 41:99-104. http://dx.doi. org/10.1016/j.clay.2007.09.010

8. Chandrasekhar S and Pramada PN. Investigation on the synthesis of zeolite NaX from Kerala kaolin. Journal of Porous Materials. 1999; 6:283-297. http://dx.doi. org/10.1023/A:1009632606671

9. Rees LVC and Chandrasekhar S. Hydrothermal reaction of kaolinite in presence of fluoride ions at $\mathrm{pH}<10$. Zeolites. 1993; 13:534-541. http://dx.doi.org/10.1016/01442449(93)90230-Z

10. Acorsi MM, Schwanke AJ, Penha FG, Pergher SBC and Petkowicz DI. Transformação de caulim em zeólita tipo P. Cerâmica Industrial. 2009; 14:28-33.

11. International Zeolite Association - IZA. Available from: $<$ http://www.iza-structure.org/databases $>$.

12. Ejhieha AN and Khorsandi M. Photodecolorization of Eriochrome Black T using NiS-P zeolite as a heterogeneous catalyst. Journal of Hazardous Materials. 2010; 176:629-637. http://dx.doi.org/10.1016/j.jhazmat.2009.11.077 of zeolite $\mathrm{NaP}$. Thus, pure zeolite $\mathrm{NaP}$ with good crystallinity was obtained at $100{ }^{\circ} \mathrm{C}$ in a 20 -hour synthesis, using kaolin waste thermally activated. This demonstrates that the time and temperature of zeolitisation has an important role in the crystallization of the desired phase. The reaction period of 20 hours for the formation of zeolite $\mathrm{NaP}$ in the conditions studied, was much shorter than the time established by the standard procedure of IZA (60 days).

\section{Acknowledgments}

The authors thank the CAPES and the Vale Company for supporting this study.

13. Zubowa HL, Kosslick H, Muller D, Richter M, Wilde L and Fricke R. Crystallization of phase-pure zeolite NaP from MCM-22-type gel compositions under microwave radiation. Microporous and Mesoporous Materials. 2008; 109:542-548. http://dx.doi.org/10.1016/j.micromeso.2007.06.002

14. Costa ML, Sousa DJL and Angélica RS. The contribution of lateritization processes to the formation of the kaolin deposits from eastern Amazon. Journal of South American Earth Sciences. 2009; 27:219-234. http://dx.doi.org/10.1016/j. jsames.2008.11.008

15. Flores SMP and Neves RF. Alumina para utilização cerâmica, obtida a partir do rejeito de beneficiamento do caulim. Cerâmica. 1997; 43(283-284):173-177. http://dx.doi. org/10.1590/S0366-69131997000400005

16. Martelli MC and Neves RF. Characterization and technological aplication for kaolin processing wastes. Materials Science Forum. 2012; 727-728:697-702. http://dx.doi.org/10.4028/ www.scientific.net/MSF.727-728.697

17. Barata MS and Angélica RS. Caracterização dos resíduos cauliníticos das indústrias de mineração de caulim da Amazônia como matéria-prima para produção de pozolanas de alta reatividade. Cerâmica. 2012; 58(345):36-42. http://dx.doi. org/10.1590/S0366-69132012000100007

18. Da Paz SPA, Angélica RS and Neves RF. Síntese hidrotermal de sodalita básica a partir de um rejeito de caulim termicamente ativado, Química Nova. 2010; 33(3):579-583. http://dx.doi. org/10.1590/S0100-40422010000300017

19. Maia AAB, Angélica RS and Neves RF. Use of industrial kaolin waste from the Brazilian Amazon region for synthesis of zeolite A. Clay Minerals. 2011; 46:127-136. http://dx.doi. org/10.1180/claymin.2011.046.1.127

20. Hildebrando EA, Angélica RS, Neves RF and ValenzuelaDiaz FR. Synthesis of zeolitic materials using as a source of $\mathrm{SiO}_{2}$ and $\mathrm{Al}_{2} \mathrm{O}_{3}$ calcined kaolin waste. Materials Science Forum. 2012; 727-728:1349-1354. http://dx.doi.org/10.4028/ www.scientific.net/MSF.727-728.1349

21. Huo Z, Xu X, Lv Z, Song J, He M, Li Z, et al. Thermal study of NaP zeolite with different morphologies. Journal of Thermal Analysis and Calorimetry. 2012; 1-5.

22. Heller-Kallai L and Lapide I. Reactions of kaolinites and metakaolinites with $\mathrm{NaOH}$-comparison of different samples (Part 1). Applied Clay Science. 2007; 35:99-107. http://dx.doi. org/10.1016/j.clay.2006.06.006

23. Cuadros J and Dudek T. FTIR investigation of the evolution of the octahedral sheet of kaolinite-smectite with progressive kaolinization. Clays and clay minerals. 2006; 54(1):1-11. http:// dx.doi.org/10.1346/CCMN.2006.0540101 
24. Albert BR, Cheetham AK, Stuart JA and Adams CJ. Investigations on P zeolites: synthesis, characterisation, and structure of highly crystalline low-silica NaP. Microporous and Mesoporous Materials. 1998; 21:133-142. http://dx.doi. org/10.1016/S1387-1811(97)00059-0
25. Zholobenko VL, Dwyer J, Zhang R, Chapple AP, Rhodes NP and Stuart JA. Structural transitions in zeolite P: An in situ FTIR study. Journal of the Chemical Society, Faraday Transactions. 1998; 94(12):1779-1781. http://dx.doi. org/10.1039/a800060c 